\title{
FISH BIO-DIVERSITY AND LIVELIHOOD OF FISHERS OF DEKAR HAOR IN SUNAMGANJ OF BANGLADESH
}

\author{
I.N. SURAVI ${ }^{1}$, M.S. ISLAM ${ }^{2}$, N. BEGUM ${ }^{3}$, M.A. KASHEM ${ }^{4}$, \\ F.J. MUNNY ${ }^{5}$ AND F. IRIS ${ }^{6}$ \\ $1 \& 3$ Department of Coastal and Marine Fisheries, Department of Coastal and Marine Fisheries, ${ }^{4}$ \\ Department of Soil Science, ${ }^{5}$ Department of Aquaculture, Sylhet Agricultural University, \\ Sylhet-3100, Bangladesh ${ }^{6}$ Teesside University, UK
}

\begin{abstract}
The study was carried out to assess the present status of fish biodiversity in Dekar haor and livelihood of fishermen living around the haor under Sunamganj district during 12 months from September 2015 to August 2016. Monthly fish samples were collected from the catches of fishermen and identified based on meristic and morphometric characteristics. A total of 51 fish species belonging to 34 genera along with two prawn species under 19 families was found. Among them catfishes were most abundant. The values of Shannon-Weiner diversity $\left(\mathrm{H}^{\prime}\right)$, Margalef's richness (d), Pielou's evenness indices $\left(J^{\prime}\right)$ and Simpson dominance indices (c) ranged from 3.36-3.78, 6.12-8.40, 0.980.99 and 0.97-0.98, respectively. Livelihood data were collected through direct interview from randomly selected 73 fishermen. Main occupation of fishermen is fishing. There were three age groups such as young (18-35 years), middle (36-45 years) and old group (above 46 years) where young group was mostly involved in fishing. Most of the fishermen (72.61\%) were Muslims and 63\% were able to sign only followed by others. Annual income of fishermen varied from Tk. 10,000-100,000. Majority of them had low savings with poor housing and sanitation facilities. Maximum fishers are interested to live in unit family owing to low income. Results of this study imply that fish diversity status was not satisfactory. Also livelihood condition of fishers was not so good. Therefore, appropriate measures should be taken to improve the livelihood of fishermen and to protect the bio-diversity of the haor.
\end{abstract}

Key words: Fish diversity, Haor, Livelihood, Fishermen

\section{Introduction}

Bangladesh possesses vast natural waterbodies in the form of canal, beel, haors, baors, lakes, floodplains, rivers and estuaries. Haors are located in the north-eastern region of Bangladesh. There are about 373 haors located in the districts of Sunamganj, Sylhet, Maulvibazar, Habiganj, Brahmanbaria, Netrokona and Kishoreganj, and covering an area of about 858,000 ha, which is around $43 \%$ of total area of the haor region (Master Plan of Haor Areas 2012). The most prominent haors are Shaneer, Hail, Hakaluki, Dekar, Tanguar, Chayer, Maker and Kawadighi haor. Haor is a marshy wetland ecosystem, which physically is a bowl or saucer shaped floodplain depression that looks like inland sea in monsoon flood. In wet season, haors are full of water and each of settlements looks like an isolated island in a vast waterbody but in dry season, these are dried up except deep beels. During winter, haors contain little water and are restricted to a small 
area, and a large area is filled with paddy and other crops. These natural depressed seasonal-perennial waterbodies are directly/indirectly connected with canal and river and other haor. These are naturally rich in fisheries resources. Waterbodies of haors are productive and natural habitats of diversified fauna and flora. These are also famous for natural fish production.

Haors play an important role to develop the fish diversity and maintained the livelihood condition of fishermen. Livelihood status of the haor dwelling fishermen mostly depends on the fisheries and other natural resources in the haor. On the other hand, fish diversity is also somewhat dependent on livelihood of fishermen. So fishing group is an important community to enrich the fish diversity and economics of Bangladesh. But most of the fishermen are poor and are deprived of many amenities of life. All time they have to struggle to survive. Livelihood condition of fishermen is not satisfactory at all because they do not get free access to the waterbody for catching fish in all seasons.

Dekar haor is one of the largest and important haor in greater Sylhet, Netrakona, Kishoreganj and Brahmanbaria districts. The area of this haor is around $252 \mathrm{~km}^{2}$. Different sizes of beels are present in the haor. All beels are submerged during rainy season. Rivers and haors are directly jointed with each other during this period. Fishes are grazed in the whole haor. They enjoy more space and more different types of feed without competition to each other. Growth of fishes increases with passing of time. Small indigenous species and short cycled fishes become marketable size within few months. Fishes of the haor are caught using various types of gear by fishermen round the year for accomplishing the expenditure of their family. So this haor has a great influence on fish diversity and livelihood of fishermen. But despite its innumerable importance, research has not yet been carried out on fish diversity as well as livelihood of fishermen of the haor. In view of the above facts, the study was undertaken to assess the fish diversity and livelihood of fishermen living around the haor.

\section{Materials and Methods}

Description of the haor and selection of study area: Dekar haor is one of the most important and the largest haor in Bangladesh. It lies between latitude $24^{\circ} 34^{\prime} \mathrm{N}$ to $25^{\circ} 12^{\prime} \mathrm{N}$ and longitude $90^{\circ} 56^{\prime} \mathrm{E}$ to $91^{\circ} 49^{\prime} \mathrm{E}$. The haor covers four upazilas namely Sunamganj Sadar, Dakshin Sunamganj, Dowarabazar and Chhatak under Sunamganj district (Fig.1). It is located $60 \mathrm{~km}$ west away from Sylhet town, which is closed to Sunamganj town. The haor is consisted of 36 small, medium and large interconnecting beels, canals, rivers and crop lands. This open waterbody was selected as a study area.

Data collection: The data were collected for 12 months (from September 2015 to August 2016). During data collection, both primary and secondary sources were considered to interpret the results. For fish diversity assessment of the haor, monthly fish samples were collected directly from the catches of fishermen for identification of the species. Some samples were identified up to species on the spot and recorded the number of specimen 


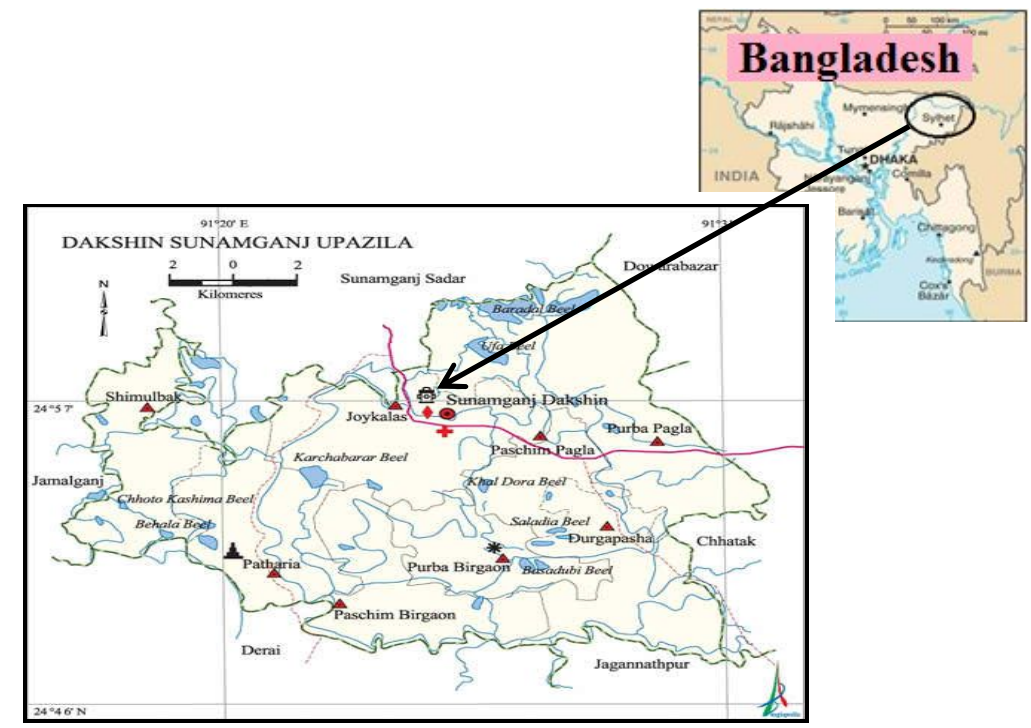

Fig. 1. Map of Dakshin Sunamganj upazila showing the study area.

and weighed species wise. Some samples were identified and recorded up to genus or species level following the manual and books of Talwar and Jhingran (1991) Shafi and Quddus (2001) DoF (2014) (2005) and Rahman.

Livelihood information data were collected based on field survey method from fishermen and others 4 different villages namely Noyagoan, Sultanpur, Robbaninagor, Sadarpur surrounding the haor under Dakshin Sunamganj upazila. Fishermen were randomly selected from both professional and subsistence fishermen groups living around the study area. Livelihood data were collected from 73 randomly selected fishermen and others 17 through questionnaires interviews, focus group discussion, market visit, etc where leaders of the fisher community, fish market leaders, fish traders, fry traders, local leaders, school teachers and community people were also present. Secondary data were collected from Dakshin Sunamganj Upazila Fisheries Office, District Fisheries Office of Sunamganj district, books, journals, reports and NGOs.

Fish diversity data analysis: Diversity of species assemblage was analyzed by ShannonWeiner index $\left(H^{\prime}\right)$ (Shannon 1949, Shannon and Weiner 1963, Pielou 1966, Margalef 1968, Ramos et al. 2006), species richness was measured by Margalef index (d) evenness was estimated by Pielou's index $\left(J^{\prime}\right)$ and dominance was determined by Simpson index (c). Values of Shannon-Weiner diversity index and Margalef richness index, Pielou's evenness index and Simpson dominance index were calculated using the following formula : 
Shannon-Weiner diversity index $\left(H^{\prime}\right): \sum_{\mathrm{i}=1}^{\mathrm{s}}[\mathrm{Pi} \times \log (P i)]$

Where, $\mathrm{H}^{\prime}=$ Shannon-Weiner index

$\mathrm{Pi}=\mathrm{ni} / \mathrm{N}$

$\mathrm{ni}=$ No. of individuals of a species

$\mathrm{N}=$ Total number of individual fish

$\mathrm{S}=$ Total number of fish species

Margalef species richness $(d):(S-1) / \log (N)$

Where, $\mathrm{S}=$ Total fish species

$\mathrm{N}=$ Total individual fish

Pielou's evenness index $\left(J^{\prime}\right): H(s) / H(\max )$

Where, $H(\mathrm{~s})=$ the Shannon-Weiner information function.

$\mathrm{H}(\max )=$. The theoretical maximum value for $\mathrm{H}(\mathrm{s})$ if all species in the sample were equally abundant.

Simpson dominance index $(c): \sum_{\mathrm{i}=1}^{\mathrm{s}}(\mathrm{ni} / \mathrm{N})^{2}$

Where, $\mathrm{ni}=$ number of individuals in the 'each' species

$\mathrm{N}=$ Total number of individual fish

$\mathrm{S}=$ Total number of fish species

Socioeconomic and livelihood data analysis: All collected socioeconomic and livelihood data were calculated using the following formula :

$$
-\sum X_{i}
$$

Mean, $\mathrm{X}=$

\section{$\mathrm{N}$}

Where, $\quad \sum \mathrm{X}_{\mathrm{i}}=$ Sum of all of the numbers in a list

$\mathrm{N}=$ Total number of items in that list

Range: It is the difference of the higher and lower observation of the distribution.

Percentage: It is the rate/number/amount in each hundred.

Statistical analysis: A one way analysis of variance (ANOVA) was used to test for significant difference in Shannon-Weiner diversity index $\left(\mathrm{H}^{\prime}\right)$, Pielou's evenness index $\left(J^{\prime}\right)$ and fish abundance among months. All multivariate analyses were performed by software PRIMER V6 (Plymouth Routines Multivariate Ecological Research) (Clark and Warwick 1994). All socioeconomic and livelihood data were stored and processed through computer software and analyzed using Microsoft Excel and STATISTICA software. 


\section{Results and Discussion}

Fish diversity of Dekar haor: Large number of freshwater fish species are still available in this largest freshwater wetland. During the study period 51 species of fish of which 8 species of carps, 4 snakehead, 8 perches, 3 eels, 11 catfishes, 6 barbs, 1 minnows, 2 clupeids and 8 other fishes including prawn namely Macrobrachium rosenbergii and Macrobrachium malcolmsonii under 19 families were recorded (Table 1). It was found that 23 fish species were abundant, 10 common and 18 rare out of 51 fish species (according to IUCN, 2015). Of 51 species, 47 were indigenous and the rest four exotics species. Among exotics, carpio (Cyprinus carpio) and grass carp (Ctenopharyngodon idella) were dominant in the haor. Pandit et al. (2015) reported a total of 56 fish species including prawn species belongs to 21 families from the haor Soma Nadi Jalmohal of Derai upazila, Sunamganj. Among 56 species, 26 were commonly available (47\%), 18 moderately available (32\%) and 12 rarely available (21\%). Out of 56 species, 8 were carps, 12 catfish, 9 barbs and minnows, 4 snakehead, 4 eel, 10 perches, 3 loaches and 6 miscellaneous including 3 prawn species. Sayeed et al. (2015) reported a total of 82 fish species belongs to 50 genera of 22 families under 9 orders, of which 75 were indigenous and 7 exotic in Hakaluki haor.

Fishermen in this haor were classified according to their fishing gear used. Nine types of gear were considered during the experimental period (Table 2). Most of the fishermen (31.51 and $16.4 \%$ ) used gill net and seine net, and only $2.74 \%$ used fish trap-b (gui) and c (polo), respectively for catching fish. Fisheries resources are now under great threat due to man-made obstacles (fishing by dewatering of beels, use of gill net, harvesting of undersized fishes and brood fishes, use of insecticides, embankment, exploitation of aquatic vegetation, etc) and various environmental degradations (siltation of the beels, lack of water around the year, lack of natural food for fishes, water quality degradation, climate/seasonal changes, etc). For these reasons, fish diversity of the haor has been reducing day by day.

Fish species diversity indices : Shannon-Weiner diversity index $\left(H^{\prime}\right)$ : The highest (3.3556) Shannon-Weiner index was recorded in February and the lowest (3.7799) in September. Kanon (2014) reported the highest value (3.12) in June and the lowest (2.9) in January of Shannon-Weiner index of Konoskhai haor, Sunamganj, which was lower than the findings of the present study.

Margalef richness index $(d)$ : The lowest (6.1185) and the highest (8.4023) values of Margalef index were recorded in February and September, respectively. Kanon (2014) reported the Margalef's index ranging from 2.7 (December) to 3.02 (July) in Konoskhai haor, which was less than the findings of this study. 
Table 1. List of indigenous and exotic fishes recorded in Dekar haor during study period.

\begin{tabular}{|c|c|c|c|c|c|}
\hline $\begin{array}{l}\text { Sl. } \\
\text { No. }\end{array}$ & Family name & Local name & English name & Scientific name & $\begin{array}{c}\text { Remarks } \\
\text { (IUCN, 2015) } \\
\end{array}$ \\
\hline 1. & Cyprinidae & Rui & Indian major carp & Labeo rohita & Rare \\
\hline 2. & Cyprinidae & Catla & Indian major carp & Jubilant catla & Common \\
\hline 3. & Cyprinidae & Kali baush & Black rohu & Labeo calbasu & Abundant \\
\hline 4. & Cyprinidae & Mrigal & Indian major carp & Cirrhinus cirrhosus & Rare \\
\hline 5. & Cyprinidae & Gonia & Kuria labio & Labeo gonius & Abundant \\
\hline 6. & Cyprinidae & Silver carp & Silver carp & \multicolumn{2}{|c|}{ Hypophthalmychthys molitrixCommon } \\
\hline 7. & Cyprinidae & Grass carp & Grass carp & Ctenopharyngodon idella & Common \\
\hline 8. & Cyprinidae & Carpio & Common carp & Cyprinus carpio & Abundant \\
\hline 9. & Channidae & Shol & Snakehead murrel & Channa striatus & Abundant \\
\hline 10. & Channidae & Taki & Spotted snakehead & Channa punctatus & Abundant \\
\hline 11. & Channidae & Chang & Asiatic snakehead & Channa orientalis & Rare \\
\hline 12. & Channidae & Gajar & Giant snakehead & Channa marulius & Rare \\
\hline 13. & Anabantidae & Khalisha & Striped gourami & Colisa fasciatus & Rare \\
\hline 14. & Anabantidae & Chuna khalisha & Honey gourami & Colisa chuna & Rare \\
\hline 15. & Anabantidae & Lal khalisha & Red gourami & Colisa lalia & Rare \\
\hline 16. & Anabantidae & Koi & Climbing perch & Anabus testudineus & Common \\
\hline 17. & Centropomiodae & Kata chanda & Round glass perchlet & Chanda baculis & Abundant \\
\hline 18. & Centropomidae & Lal chanda & Indian glass perch & Chanda ranga & Rare \\
\hline 19. & Centropomidae & Nama chanda & Elongated glass perchlet & Chanda nama & Abundant \\
\hline 20. & Nandidae & Meni & Mud Perch & Nandus nandus & Abundant \\
\hline 21. & \multicolumn{2}{|c|}{ Mastacembelidae Guchi baim } & Striped spiny eel & Mastacembelus pancalus & Abundant \\
\hline 22. & \multicolumn{2}{|c|}{ Mastacembelidae Tara baim } & One striped spiny eel & Macrognathus aculeatus & Abundant \\
\hline 23. & \multicolumn{2}{|c|}{ Mastacembelidae Lal baim } & Tire-track spiny eel & Mastacembelus armatus & Abundant \\
\hline 24. & Bagridae & Gulsha & Long whiskered catfish & Mystus gulio & Common \\
\hline 25. & Bagridae & Bujuri & Long bled catfish & Mystus tengra & Abundant \\
\hline 26. & Bagridae & Tengra & Striped dwarf catfish & Mystus vittatus & Abundant \\
\hline 27. & Bagridae & Air & Long whiskered catfish & Sperata aor & Rare \\
\hline 28. & Claridae & Magur & Walking catfish & Clarius batrachus & Abundant \\
\hline 29. & \multicolumn{2}{|c|}{ Heteropneustidae Shing } & Stinging catfish & Heteropneustes fossilis & Abundant \\
\hline 30. & Schilbeidae & Batashi & River catfish & \multicolumn{2}{|c|}{ Pseudeutropius atherinoides Common } \\
\hline 31. & Schilbeidae & Bashpata & Gangetic ailia & Ailia coila & Common \\
\hline 32. & Schilbeidae & Bacha & River catfish & Eutropiichthys vacha & Rare \\
\hline 33. & Siluridae & Modhu pabda & Butter catfish & Ompok pabda & Common \\
\hline 34. & Siluridae & Boal & Freshwater shark & Wallago attu & Abundant \\
\hline 35. & Cyprinidae & Phul chela & Barb & Chela phulo & Rare \\
\hline 36. & Cyprinidae & Lamba chela & Barb & Chela bacaila & Rare \\
\hline 37. & Cyprinidae & Mola & Barb & Amblypharyngodon mola & Common \\
\hline 38. & Cyprinidae & Dhela & Barb & Rohtee cotio & Rare \\
\hline 39. & Cyprinidae & Jatpunti & Spot fin swamp barb & Puntius sophore & Abundant \\
\hline 40. & Cyprinidae & Tit punti & Fire fin barb & Puntius ticto & Abundant \\
\hline 41. & Cyprinidae & Darkina & Top minnow & Esomus dandricus & Rare \\
\hline 42. & Clupeidae & Chapila & Indian river shad & Gudusia chapra & Abundant \\
\hline 43. & Clupeidae & - & Indian river shad & Gudusia minminna & Abundant \\
\hline 44. & Belonidae & Kakila & Freshwater gar fish & Xenentodon cancila & Abundant \\
\hline 45. & Cobitidae & Gutum & Guntea loach & Lepidocephalus guntea & Rare \\
\hline 46. & Gobiidae & Baila/bele & Bar-eyed goby & Glossogobius giuris & Common \\
\hline 47. & Notopteridae & Chitol & Humped feather back & Notopterus chitala & Rare \\
\hline 48. & Palaemonidae & Golda & River prawn & $\begin{array}{l}\text { Macrobrachium } \\
\text { rosenbergii }\end{array}$ & Rare \\
\hline 49. & Palaemonidae & Gura chingri & $\begin{array}{l}\text { Monsoon river } \\
\text { prawn }\end{array}$ & $\begin{array}{l}\text { Macrobrachium } \\
\text { malcolmsonii }\end{array}$ & Abundant \\
\hline 50 & Tetraodontidae & Choto tepa & Oscillated puffer fish & Tetraodon cutcutia & Abundant \\
\hline 51. & Cichlidae & Tilapia & Tilapia & $\begin{array}{l}\text { Oreochromis } \\
\text { mossambicus }\end{array}$ & Rare \\
\hline
\end{tabular}


Pielou's evenness index $\left(J^{\prime}\right)$ : The highest evenness value $(0.9965)$ was observed in February and the lowest (0.9885) in November. Alam et al. (2015) recorded Pielou's index as 0.67, 0.59 and 0.67, respectively in three beels (Patasinghra, Shalkatua and Hawagulia of Kawadighi haor), Moulvibazar, which were lower than the present findings.

Table 2. Fishing gears used in Dekar haor during study period.

\begin{tabular}{l|ll}
\hline \multicolumn{1}{c|}{ Groups } & & \multicolumn{1}{c}{ Types of gear } \\
\hline & Gill net & Current jal \\
& Seine net & Ber jal \\
Fish net & Lift net & a. Vassal/Khorajal \\
& bast net & Jhaki jal jal \\
& Push net & Thela jal \\
\hline
\end{tabular}

\begin{tabular}{ll}
\hline & a. Tengra chai \\
Fish trap & b. Gui \\
& c. Polo \\
& $\bullet$ Dori \\
& $\bullet$ Kon \\
& $\bullet$ Ronga \\
\hline \multirow{2}{*}{ Hooks and line } & a. Borshi \\
& b. Hand borshi \\
\hline
\end{tabular}

Simpson dominance index (c): The uppermost dominance value (0.9819) was determined in June and the lowest (0.9747) in February. Kanon (2014) demonstrated Simpson index ranging from 0.91 (January) to 0.94 (June) in Konoskhai haor, which was coincided with the findings of the present study. It is noted that water area of the haor is gradually/drastically increased after first/mid/last April in a year due to heavy shower and upstream run-off/flash flood. Fishes are dispersed in the whole haor. Fishermen freely catch fishes from the non-restricted water using different types of gear for their livelihood. Fishermen catch gradually increase with the increases of time up to a certain period, while water of the haor gradually recedes, comparatively a good amount of fishes are caught by fishermen. Peak season of fishing is started from June/July and continue up to October/November in a year. After that water is limited to certain areas and fishermen are not allowed for catching fish from restricted/leased water-bodies. For these causes, monthly catch by fishermen varied with season and water availability. 


\section{Livelihood status of fishermen}

Age structure: Age structure of fishermen was divided into three age groups such as young (18-35 years), middle (36-45 years) and old age (above 46 years). It was observed that young group was the highest (59\%) and old was the lowest (19\%) among all gear users. Within fishing gears, young group was the highest (100\%) in trap-c (polo) users and in the middle group the highest percentage (66.67\%) was observed for push net whereas the highest value (50\%) was estimated for old group in case of trap-b (gui) users. Rabbani (2007) reported that age group of 25-50 years was the highest $(46.67 \%)$ and more than 50 years were the lowest (25\%) of fishermen in the Karatua river, Bogra. Roy (2010) stated that young group was the highest (42\%) and old group was the lowest (34\%) among all gear users, these were consistent with the findings of the present study.

Family size: About $48 \%$ fishermen had medium family, $31 \%$ small and $21 \%$ large. Within the fishermen according to gear types, the highest percentage (100\%) of medium family belonged to cast net, push net and trap-c (polo) users, and the lowest of small family was recorded in long line users. The highest value (50\%) of large family was observed in trap-b (gui) users. Roy (2010) reported the largest value $(83.33 \%$ ) of medium family belongs to trap-b (gui) users and the lowest of large family among all gear users.

Religion: Sampled fishermen were distributed as $72.61 \%$ the Muslims and $27.39 \%$ the Sonatans, respectively in the haor, which was in agreement with the findings of Mahmud (2007) and Roy (2010), who stated that the highest 74 and $71 \%$ fishermen were the Muslim whereas only 26 and 29\% the Hindus (Sonatans). Himu (2014) mentioned that majority (95.14\%) of fishermen was the Muslims and minority (4.85\%) the Hindus in study area of Hakaluki haor, which was higher than the findings of the present study.

Educational status: Sixty three percent (63\%) fishermen had ability to sign, $26 \%$ no education and $7 \%$ primary. On the other hand, only 3\% and $1 \%$ fishermen had JSC (Junior School Certificate) and SSC (Secondary School Certificate). Rabbani (2007) reported $20 \%$ riverine fishermen illiterate, $71.67 \%$ primary and only $8.33 \%$ secondary level. It might be due to the majority of the fishermen had no education. Roy (2010) stated that 73\% fishermen of Pagnar haor in Sunamganj had no education, 21\% primary and only $6 \%$ secondary. Most of sampled fishermen were compelled to engage in fishing profession at their early stage due to poor economic condition of their parents and lack of awareness about education.

Annual income: A 51\% fishermen had moderate income and $11 \%$ low income whereas $38 \%$ high income. Annual income varied within different types of gear used by fishermen (Fig. 2). Majority of the cast net (100\%) and gill net (82.61\%) users had moderate income and most of the push net and multiple gear users (66.66\%) were fell in low income group. Maximum multiple gear users (73.34\%) had high income. Fishermen opine that their income depend on the availability of fishes in the haor. The quantity of fishes in the haor has been decreasing in every year owing to natural and man-made 
causes. On the whole life, fishermen are at risk and they have no refreshment and no different taste of life. So many fishermen are switching over fishing profession to other

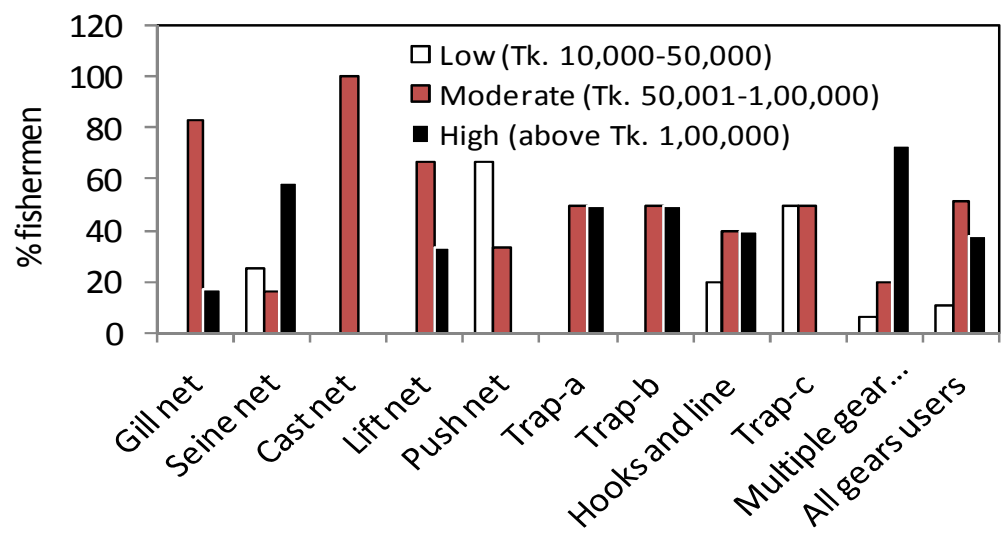

Annualincome based on gear type

Fig. 2. Annual income of fishermen of Dekar haor.

activities to enjoy better life. Roy (2010) stated that the highest (7.14\%) annual income was in long line fishermen under high annual income category. Comparatively maximum income $(85.72 \%)$ was recorded in long line users under moderate income and the highest $(50 \%)$ income was found in trap-b (gui) users under low income. He also concluded that long line fishermen earned comparatively higher income than other two categories. Holder (2002) reported annual income from fishing of all gear users as Tk. 89,199.96 and 96,199.92 in Doba beel and Chara beel, respectively. Himu (2014) observed that only $21.37 \%$ fishermen continued their livelihood generation through fishing. Majority (78.63\%) of them took other occupations due to low income from fishing. He concluded that livelihood of fishermen were not satisfactory.

Savings: Savings of haor fishermen are presented in Fig. 3. About $38 \%$ respondents had medium savings, $41 \%$ low, $11 \%$ no savings and $10 \%$ high savings. Within fishing gear categories, majority (75\%) of trap-a (chai) users had medium savings and $66.67 \%$ push net users had no savings at all, whereas about 50\% trap-b (gui) users had high savings. It was also found that maximum of trap-b (gui) and multiple gear users were saved from their income. Roy (2010) reported that low savings group was the highest (55\%) and high savings group was the lowest among all gear users. He also added that within fishing gear users no savings group was the highest (35.72\%) in cast net and long line users, low savings group was the highest $(83.33 \%$ ) in trap-b (gui) users and medium savings group $(46.66 \%)$ was in gill net users. 


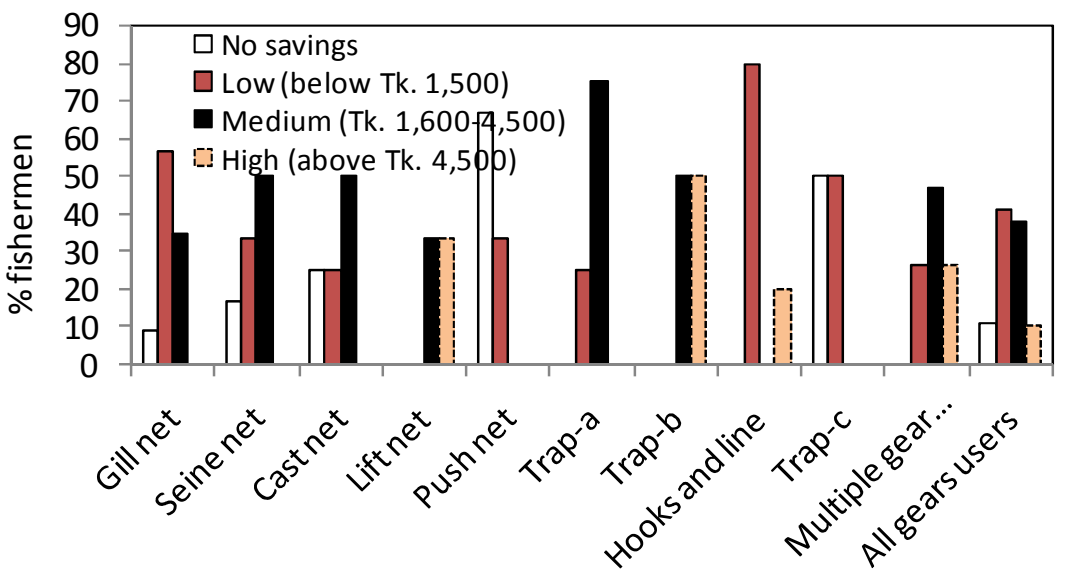

Fishermen's savings based on gear type

Fig. 3. Savings status of fishermen of Dekar haor.

Housing and health condition: There were two types of house in the study area namely thatched house and half building (brick walls with tin roof). Data of the present study revealed that $83.56 \%$ fishermen had thatched houses and $16.44 \%$ half building. Ahmed (2002) found that $62 \%$ fishermen had thatched houses in Mymensingh. Roy (2010) observed that majority of fishermen $(83 \%)$ had thatched house and $17 \%$ half building in the Pagnar haor, Sunamganj. Himu (2014) noted that about $66.66 \%$ fishermen had thatched house, while $26.66 \%$ half building and only $6.66 \%$ building surrounding the Hakaluki haor. Health facilities of fishermen in studied area were very poor and found that $54.79 \%$ fishermen households dependent on village doctors who do not have any knowledge regarding medical science, 23.28 and $19.18 \%$ on quack doctor and municipal hospital, respectively while only $2.74 \%$ received health service from MBBS doctor. Roy (2010) mentioned 85\% fishermen in Pagnar haor, Sunamganj dependent on village doctors and $15 \%$ received health service from upazila hospital. Alam (2006) reported only $42 \%$ farmers received the medical facilities from MBBS doctor and upazila health complex while the rest $58 \%$ dependent on village doctor and others in Mithapuqur upazila, Rangpur.

Sanitation facilities: Sanitation facilities of fishermen living around the haor were not good. Data showed that $79.45 \%$ had open toilets surrounded by temporary fencing while $20.55 \%$ sanitary. Alam (2006) reported that only $24 \%$ had good sanitation. Roy (2010) observed that $40 \%$ had open toilets, only $8 \%$ sanitary and $52 \%$ had no toilets. Himu (2014) found that most of the fishermen had the worth toilet facilities, $58.33 \%$ had open toilet, whereas $3.66 \%$ no toilet facility. 
Land area: Majority (49\%) of fishermen had small land whereas only $14 \%$ large. On the other hand, $37 \%$ respondents had medium land. According to gear types the largest value $(66.66 \%)$ of small land holder in lift net users and in case of long line users about $40 \%$ had large whereas $66.66 \%$ push net users had medium land.

Family type: There were two types of family in the study area such as joint family and unit family. Approximate $16.44 \%$ fishermen lived in joint family and $83.56 \%$ in unit family. Roy (2010) noted that 56\% fishermen lived in joint family and $44 \%$ in nuclear (small) family. Himu (2014) observed that most of fishermen had nuclear family $(90 \%)$ while few $(10 \%)$ joint family, which was coincided with the findings of the present study. Joint/large family is splitting owing to majority respondents are interested to live separately due to lack of income.

Results of the study indicate that indiscriminate fishing activities using different types of gears by fishermen caused great loss of all varieties of fishes and the status of fish biodiversity is now moderate to poor. Most of the fishermen's income is much lower than the national per capita income. Fishermen's savings are very poor. Their livelihood condition is not good. Majority of the fishers are changing their livelihood as fish diversity and fish production of the haor are decreasing in every year due to man-made and natural causes. Government and other organizations should come forward for taking urgent actions to protect the biodiversity of the haor, which will help to improve fishermen's livelihood and fish diversity will be saved.

\section{Acknowledgements}

The authors are indebted to the Krishi Gobeshona Foundation (KGF) for providing fund to conduct the research under the project entitled "Farm Productivity Improvement in Haor areas through Integrated Farming Systems Approach".

\section{References}

Ahmed, N. 2002. Socio-economic aspects of freshwater prawn culture development in Mymensingh. Bangladesh. A report prepared for ICLARM, Dhaka. $25 \mathrm{p}$.

Alam, M. J. 2006. Status of fish farming and livelihood of the fish farmers in Mithapukur, Rangpur. M. S. Thesis (unpublished), Department of Fisheries Management, Bangladesh Agricultural University (BAU), Mymensingh. 81 p.

Alam, M. T., M. A. H. M. Kamal, M. A. Sayeed and M. A. Kabir. 2015. Impact of Aquaculture on Fish Biodiversity in KawadighiHaor of North- East Region of Bangladesh. SAU Res. Prog. Rep. No. 02, Sylhet Agricultural University, Sylhet, Bangladesh, pp. 51-56.

Clarke and Warwick, 1994. Change in Marine Communities: An Approach to Statistical Analysis \& Interpretation. Natural Environment Research Council, UK, 144 p.

DoF (Department of Fisheries). 2014. Freshwater Fishes of Bangladesh. Department of Fisheries, Bangladesh. 213 p.

Himu, M. H. 2014. Impact of fish biodiversity on fishers livelihood of Hakaluki haor in Bangladesh. M. S. Thesis (unpublished), Department of Fisheries Technology and Quality Control, Sylhet Agricultural University, Sylhet. 60 p. 
Holder, D. K. 2002. Studies on the availability of small indigenous species (SIS) of fishes and socioeconomic condition of fishers in two beels of rice fields. M. S. Thesis (unpublished), Department of Fisheries Management, Bangladesh Agricultural University, Mymensingh. 136 p.

IUCN (International Union for Conservation of Nature) Bangladesh. 2015. Red List of Bangladesh, Vol. 5: Freshwater Fishes, Bangladesh Country Office, Dhaka, Bangladesh. pp. $\mathrm{xvi}+360 \mathrm{p}$.

Kanon, M. H. 2014. Diversiity of Indigenous Fish Species in Konoskhai Haor. M.S. Thesis (unpublished) submitted to the Department of Fish Biology and Genetics, Sylhet Agricultural University (SAU), Sylhet. 49 p.

Mahmud, T. A. 2007. Fish biodiversity and socio-economic conditions of the fishing community in some selected areas of Chalan beel. M. S. Thesis (unpublished) submitted to the Department of Aquaculture, BAU, Mymensingh. pp. 27-53.

Margalef, R. 1968. Perspectives in Ecological Theory. Chicago Illinois University. Chicago Press. $111 \mathrm{p}$.

Master Plan of Haor Areas. 2012. Draft Final Report, Vol. II, Ministry of Water Resources, Bangladesh Haor and Wetland Development Board, Government of the People's Republic of Bangladesh, pp. 1-18.

Pandit, D., M. Kunda, M. J. Islam, M. A. Islam and P. P. Barman. 2015. Assessment of present status of fish diversity in Soma NadiJalmohal of Sonamganj in Bangladesh. J. Sylhet Agril. Univ., 2 (1): 127-135.

Pielou. 1966. The measurement of Diversity in Different Types of Biological Collections. Theort. Biology, 13:131-144.

Rabbani, M. G. 2007. Study on the fisheries and socio-economic condition of fishermen of Karatua river. M. S. Thesis (unpublished), Department of Fisheries Management, BAU, Mymensingh. 85 p.

Rahman, A. K. M. 2005. Freshwater Fishes of Bangladesh. 2nd ed. Zoo. Soc. of Bangladesh, Dhaka, Bangladesh. 394 p.

Ramos, S., R. K. Cowen, P. Re' andA. A. Bordalo. 2006. Temporal and patial distribution of larval fish assemblages in the Lima estuary (Portugal). Estuarine, Coastal and Shelf Science, 66: 303-314.

Roy, K. C. 2010. Fish biodiversity and the livelihoods of the fishing community in Pagnarhaor under Jamalgonjupzila in Sunamgonj district. M.S. Thesis (unpublished), Department of Aquaculture, Bangladesh Agricultural University, Mymensingh.

Sayeed, M. A., R. C. Deb, D. Bhattarcharjee, M. H. Himuand and M. T. Alam. 2015. Fish biodiversity of Hakalukihaor in north-east region of Bangladesh. SAU Res. Prog. Rep. No. 02, Sylhet Agricultural University, Sylhet, Bangladesh, pp. 71-78.

Shafi, M. and M. M. A. Quddus. 2001. Bangladesher Matshaw Sampad (Bangla). Kabir Publications, Dhaka. 485 p.

Shannon, C. E. 1949. Communities in the presence of noise proceeding of the Institute of Radio Engineers, 37 (1): 10-21.

Shannon, C. E. and W. Weiner. 1963. The mathematical Theory of communications. University of Illinois Press, Urbana, II, 125 p.

Talwar, P. K. and A. G. Jhingran. 1991. Inland fishes of India and adjacent countries. Volume 1 and 2. Oxford and IBH Publishing Co. Pvt. Ltd. New Delhi, Calcutta. 1158 p.

(Revised copy received on 10-12-2017) 